\title{
ANALISIS KETERAMPILAN MENARIK KESIMPULAN DALAM PEMBELAJARAN FISIKA PESERTA DIDIK DI SMA NEGERI 9 MAKASSAR
}

* Riska Irmayadi

Universitas Negeri Makassar riskairmayadi@gmail.com

\section{Abdul Haris \\ Universitas Negeri Makassar abd.haris@unm.ac.id \\ Kaharuddin \\ Universitas Negeri Makassar kaharuddin@unm.ac.id}

* Koresponden Author
Abstrak - Penelitian ini merupakan penelitian deskriptif kuantitatif yang bertujuan untuk mendeskripsikan keterampilan menarik kesimpulan peserta didik. Subjek penelitian ini adalah peserta didik kelas XII MIA IV di SMAN 9 Makassar. Penelitian ini menggunakan tes keterampilan menarik kesimpulan. Hasil penelitian menunjukkan bahwa keterampilan peserta didik dalam menarik kesimpulan secara deduksi berada pada kategori sedang sementara secara induksi berada pada kategori kurang. Hasil penelitian juga menunjukan bahwa keterampilan menarik kesimpulan secara deduksi lebih dominan dibandingkan keterampilan menarik kesimpulan secara induksi. Hal ini disebabkan oleh jarangnya penggunaan keterampilan menarik kesimpulan dalam pembelajaran fisika dan kurangnya penggunaan metode induksi dibandingkan dengan deduksinya.

Kata Kunci : Deduksi, Induksi, Keterampilan Menarik kesimpulan.

Abstract - This research is a quantitative descriptive research that aims to describe student's skills of drawing conclusions. The research subjects were students of class XII MIA IV at SMAN 9 Makassar. This reseach uses a conclusion drawing skills test. The results showed that the students' skills in drawing conclusions by deduction were in the medium category while induction was in the less category. The results also showed that deduction conclusion drawing skills were more dominant than induction drawing skills. This is due to the infrequent use of conclude skills in learning physics and the lack of use of the induction method compared to its deduction.

Keywords: Deduction, Drawing conclusion skills, Induction 


\section{A. PENDAHULUAN}

Proses pembelajaran menurut Permendikbud no 22 (2016: 1) diselenggarakan secara menantang dan menyenangkan serta memotivasi peserta didik untuk berpartisipasi aktif, serta memberikan ruang untuk perkembangan fisik dan psikologi peserta didik. Proses belajar juga harus memberikan kesempatan pada peserta didik untuk mengkontruksi pengetahuan dalam proses kognitifnya (Suharto, 2015: 15).

Penalaran dan argumentasi merupakan salah satu aspek penting dalam proses pembelajaran sains. Keterampilan bernalar dan melakukan argumentasi mempermudah seseorang dalam mengumpulkan informasi dan mengambil keputusan, mengajukan suatu pendapat serta menguji ide atau gagasan yang ada. Argumentasi juga digunakan untuk mengkomunikasikan suatu pendapat (claim) dengan menyediakan beberapa data penunjang untuk meyakinkan pembaca atau lawan komunikasi terhadap kebenaran klaim tersebut. Dalam pendidikan sains, argumentasi membantu pembentukan informasi baru dan membangun suatu pemahaman baru.

Peserta didik dengan keterampilan argumentasi yang baik akan dapat menyimpulkan kenapa suatu pernyataan memiliki tingkat kebenaran yang lebih tinggi dibanding pernyataan lainnya. Seorang peserta didik dapat menyatakan klaimnya atau kesimpulannya dihadapan peserta didik lainnya ditunjang oleh data-data, pengalaman dan pengetahuan yang dimilikinya lalu peserta didik lainnya bisa saja memiliki klaim yang berbeda terhadap materi atau subjek tersebut dan dapat membantah klaim atau kesimpulan peserta didik yang pertama jika dia memiliki data penunjang yang lebih baik dan lebih valid dibandingkan dengan peserta didik yang mengajukan klaim atau kesimpulan sebelumnya. Keterampilan berpikir induksi dan deduksi sama pentingnya bagi peserta didik untuk menarik kesimpulan. Kedua keterampilan berpikir ini digunakan dalam penggunaan metode keilmuan (Suriasumantri, 2015: 42-43). Pendekatan berbasis proses keilmuan sendiri adalah salah satu pendekatan pembelajaran yang diberlakukan dalam kurikulum 2013 (Suharto, 2015: 15-16).

Deduksi memiliki tingkat kepercayaan yang tinggi dalam premis-premisnya sehingga dapat menyatakan sesuatu benar atau salah dengan jelas sedangkan induksi sekalipun tidak mampu membenarkan atau menyatakan suatu objek atau fenomena salah dengan yakin, induksi berpartisi besar dalam kemajuan pengetahuan manusia dengan data-datanya yang pendukungnya. Pembelajaran fisika dibangun oleh proses pemikiran deduksi yang logis yang bersifat rasional dan induksi untuk melihat apakah hasil pemikiran logis tersebut berlaku di dunia empiris atau sesuai dengan kenyataan yang terjadi.

Keterampilan menarik kesimpulan penting dalam pembelajaran sains dalam hal ini terkhusus pada pembelajaran fisika karena kesimpulan adalah hasil dari penalaran induksi atau deduksi dalam memperoleh suatu pengetahuan untuk memperoleh pemahaman dan pengetahuan baru.

Keterampilan menarik kesimpulan juga memungkinkan peserta didik mampu menilai sejauh mana pengetahuan baru yang mereka peroleh dapat dipercaya. Secara singkat dapat dikatakan bahwa 
keterampilan menarik kesimpulan sangat penting dalam pembelajaran fisika karena dengan keterampilan ini peserta didik dapat memperoleh pengetahuan dari pengamatan yang dilakukannya atau dengan menghubungkan suatu fenomena dengan pengetahuan yang telah mereka ketahui sebelumnya.

Peneliti melakukan observasi pada peserta didik SMA Negeri 9 Makassar melalui pendidik mata pelajaran Fisika di sekolah tersebut. Pendidik menyatakan bahwa peserta didiknya masih kurang mampu menarik kesimpulan pada proses pembelajaran fisika.

Berdasarkan uraian di atas, peneliti tertarik melakukan penelitian di SMA Negeri 9 Makassar untuk menyelidiki gambaran mengenai keterampilan menarik kesimpulan SMA Negeri 9 Makassar yang berjudul "Analisis Keterampilan Menarik Kesimpulan dalam Pembelajaran Fisika Peserta Didik SMA Negeri 9 Makassar".

\section{B. METODE}

Penelitian ini merupakan penelitian deskriptif kuantitatif. Penelitian ini bertujuan untuk memberikan gambaran umum mengenai keterampilan menarik kesimpulan peserta didik XII MIA SMA Negeri 9 Makassar.Sampel dalam penelitian ini adalah peserta didik kelas XII MIA 3 SMA Negeri 9 Makassar sebanyak 34 peserta didik.

Pengumpulan data dilaksanakan dengan memberikan instrumen tes keterampilan menarik kesimpulan. Skor untuk jawaban benar adalah 1, sementara untuk jawaban yang salah skornya adalah 0. Instrumen yang diberikan adalah instrumen tes keterampilan menarik kesimpulan yang telah divalidasi oleh pakar dengan menggunakan uji Gregory, validasi kriteria untuk skor dikotomi dengan menggunakan korelasi bieserial-point sementara reliabilitas dihitung menggunakan KR-20.

\section{HASIL DAN PEMBAHASAN}

Kemampuan menarik kesimpulan dibagi kedalam dua dimensi yaitu deduksi dan induksi. Perolehan skor statistik keterampilan menarik kesimpulan dapat dilihat dalam tabel 1. Derdasarkan hasil analisis tabel 1 terlihat bahwa skor maksimum yang dicapai pada kemampuan menarik kesimpulan secara deduksi adalah 8 dari skor ideal tertinggi 11 sedangkan skor tertinggi untuk menarik kesimpulan secara deduksi adalah 4 dari skor ideal tertinggi 8.

Pengkategorian yang digunakan untuk mengkategorikan kemampuan menarik kesimpulan adalah adaptasi dari riduwan. Pengkategorian kemampuan menarik kesimpulan secara lengkap ditunjukan oleh tabel 2. 
Tabel 1. Statistik skor hasil keterampilan menarik kesimpulan dalam pembelajaran fisika peserta didik SMA Negeri 9 Makassar.

\begin{tabular}{lcc}
\hline \multirow{1}{*}{ Statistik } & \multicolumn{2}{c}{ Skor Statistik } \\
\cline { 2 - 3 } & Deduksi & Induksi \\
\hline Jumlah sampel & 34 & 34 \\
$\begin{array}{l}\text { Skor ideal } \\
\text { tertinggi }\end{array}$ & 11 & 9 \\
$\begin{array}{l}\text { Skor ideal } \\
\text { terendah }\end{array}$ & 0 & 0 \\
Skor tertinggi & & \\
Skor terendah & 8 & 4 \\
Rata-rata skor & 1 & 0 \\
$\quad$ Standar deviasi & 4.76 & 2.18 \\
\hline
\end{tabular}

Tabel 2. Pengkategorian keterampilan menarik kesimpulan dalam pembelajaran fisika peserta didik SMA

\begin{tabular}{|c|c|c|}
\hline Jenis Penarikan Kesimpulan & Persentase $(\%)$ & Kategori \\
\hline Dedukdi & 43.31 & Sedang \\
\hline Induksi & 24.18 & Kurang \\
\hline
\end{tabular}

Dari tabel 2 dapat diketahui bahwa sekalipun kemampuan menarik kesimpulan peserta didik secara deduksi masuk ke dalam katogeri sedang, kemampuan menarik kesimpulan peserta didik secara induksi masih kurang.

Skor yang diperoleh peserta didik dalam menarik kesimpulan disajikan dalam bentuk persentase. Tampilan skor dalam persentase bertujuan untuk membandingkan skor kemampuan menarik kesimpulan secara deduksi dan induksi yang memiliki jumlah butir soal yang berbeda. Persentase skor yang diperoleh masing-masing peserta didik secara lengkap ditunjukan oleh gambar.1.

Gambar 1 menunjukkan bahwa dari 35 orang peserta didik hanya ada 9 orang peserta didik yang memiliki persentase skor keterampilan menarik kesimpulan secara induksi lebih dominan dari persentase skor keterampilan menarik kesimpulan secara deduksi.

Indikator dalam penelitian keterampilan menarik kesimpulan dalam pembelajaran fisika dalam penelitian ini secara keseluruhan terdiri dari empat indikator, indikator pertama dan kedua mewakili keterampilan menarik kesimpulan secara deduksi dan dua indikator lainnya adalah indikator yang mewakili keterampilan menarik kesimpulan secara induksi. Persentase rata-rata jumlah siswa yang menjawab benar pada setiap indikatornya seperti yang terlihat pada gambar 2 .. 


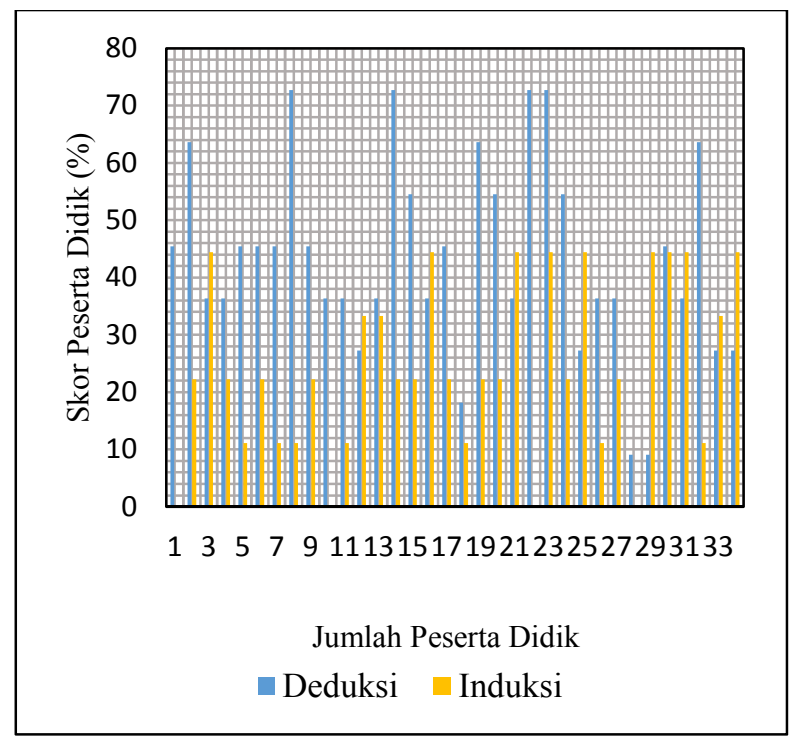

Gambar 1. Perbandingan persentase skor keterampilan menarik kesimpulan peserta didik dalam pembelajaran fisika.

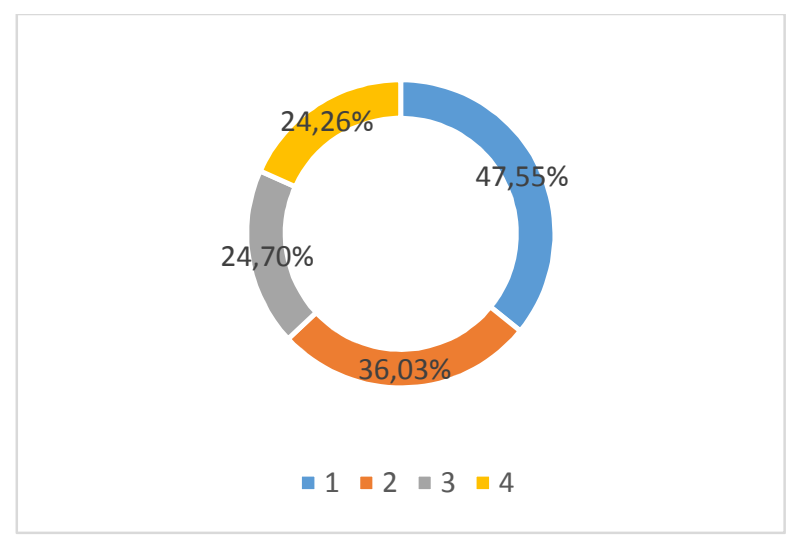

Gambar 2. . Persentase rata-rata jumlah siswa yang menjawab benar/ indikator.

Ket: Indikator 1.a (1). Indikator 1.b (2). Indikator 2.a (3). Indikator 2.b (4)

Gambar 2 menunjukan bahwa dua indikator dengan persentase rata-rata jumlah siswa yang menjawab benar/indikator tertinggi adalah indikator yang mewakili deduksi sementara dua indikator yang mewakili induksi berada pada posisi terendah.

Perolehan persentase skor keterampilan menarik kesimpulan peserta didik dalam pembelajaran fisika secara umum, deduksi dan induksi dibandingkan dalam gambar 1. Dari histogram tersebut dapat dilihat bahwa kebanyakan peserta didik memiliki keterampilan menarik kesimpulan yang dominan pada keterampilan menarik kesimpulan secara deduksi.

Hasil ini juga didukung oleh informasi yang didapatkan dari subjek penelitian mengatakan bahwa mereka lebih sering diminta untuk menyelesaikan soal-soal yang mengindikasikan bahwa pembelajaran fisika yang mereka lakukan kebanyakan melakukan pendekatan tradisional, dimana pendekatan ini mengajarkan sains secara deduktif, pembelajaran ini dimulai dengan mempresentasikan prinsip dasar dalam pembelajaran dan dilanjutkan dengan pengulangan dan aplikasi oleh peserta didik (Prince \& Felder, 2006: 134-135). 
Pembelajaran fisika di SMA dalam kurikulum 2013 menyarankan pembelajaran fisika dilakukan dengan pendekatan saintifik dan pendekatan metode keilmuan dimana pendekatan-pendekaran ini merujuk pada metode pembelajaran yang mengembangkan keterampilan induksi. Pernyataan ini didukung oleh hasil penelitian Prince \& Felder (2006: 135) yang mengatakan bahwa penggunaan metode pembelajaran inquiry, pembelajaran berbasis masalah, pembelajaran berbasis proyek, dan pembelajaran discovery meningkatkan keterampilan induksi. Hasil keterampilan menarik kesimpulan secara induksi yang lebih rendah dibandingkan dengan keterampilan menarik kesimpulan secara deduksi ini berbanding terbalik hasil yang diharapkan dengan penggunaan pendekatan yang diharapkan oleh kurikulum 2013.

Pengkategorian keterampilan menarik kesimpulan peserta didik deduksi dan induksi ditampilkan dalam table 2, dimana dari tabel tersebut dapat diketahui bahwa sekalipun kemampuan menarik kesimpulan peserta didik secara deduksi termasuk kategori sedang sementara keterampilan menarik kesimpulan peserta didik induksi masuk kedalam kategori kurang.

Hasil penelitian ini disayangkan karena keterampilan penarikan kesimpulan yang rendah sebagai suatu hasil dari proses penalaran dan sebagai salah satu komponen argumentasi (Moore \& Parker, 2012: 9) secara tidak langsung mengindikasikan bahwa keterampilan bernalar dan berargumentasi peserta didik juga rendah padahal berdasarkan hasil penelitian (Markawi, 2015: 20) keterampilan bernalar berkontrubisi sekitar 5,06 \% terhadap hasil belajar fisika. Penelitian lainnya yang dilakukan (Bhat, 2016: 86) menunjukan bahwa keterampilan beargumentasi yang baik meningkatkan perolehan akademis yang lebih baik. Sriyansyah \& Saepuzaman (2017: 21-24) penalaran saintifik adalah faktor yang mempengaruhi pemahaman peserta didik dan mempengaruhi performa peserta didik dalam pembelajaran.

Penalaran juga memiliki hubungan erat dengan matematika atau bisa dikatakan bahwa ciri utama dari matematika adalah metode dalam penalaran (Suriasumantri, 2015: 228). Penarikan kesimpulan secara deduksi menggunakan logika metematika untuk mencapai kesimpulannya dan berdasarkan penelitian dari Nurlailiyah \& Deta (2015: 68), Haryadi \& Pujiastuti (2015: 177) pengaruh keterampilan matematis sangat signifikan terhadap hasil belajar fisika. Hasil dua penelitian terakhir ini sebenarnya tidak banyak berkaitan dengan penelitian keterampilan menarik kesimpulan dalam pembelajaran fisika mengingat pengaruh matematika yang dimaksud berpengaruh signifikan terhadap hasil belajar fisika dalam penelitian yang mereka lakukan bisa saja mencangkup area matematika yang lebih luas dibandingkan dengan logika matematika yang digunakan dalam pengambilan kesimpulan secara deduksi.

Gambar 1 menujukkan persentase rata-rata jumlah jawaban benar pada setiap indikator, dari diagram tersebut dapat dilihat bahwa dua indikator yang memperoleh persentase jawaban benar tertinggi adalah indikator yang mewakili deduksi, sedangkan dua indikator yang mewakili induksi memiliki persentase yang lebih rendah. Hal yang menarik dari bagan ditunjukkan dengan persentase jumlah siswa yang menjawab benar untuk indikator 1.a dan 2.b. Indikator 1.a adalah mengetahui 
bahwa keputusan yang diambil benar dan salahnya dinyatakan dengan jelas sementara indikator 2.b adalah mengetahui bahwa keputusan yang diambil tidak bisa dinyatakan benar dan salahnya secara jelas (kebenaran kesimpulan bersifat kemungkinan). Kedua indikator tersebut menjadi indikator dengan persentase jawaban benar tertinggi dan terendah diantara empat indikator yang ada yang berarti bahwa peserta didik lebih mudah membuat keputusan yang kebenarannya dinyatakan dengan jelas dibandingkan dengan yang kebenarannya hanya dapat dinyatakan dengan kemungkinan sementara indikator 1.b dan 2.a memiliki selisih persentase rata-rata jumlah siswa yang menjawab benar yang tidak jauh berbeda.

Informasi lain yang didapatkan dari peserta didik mengatakan bahwa selain pendekatan tradisional, peserta didik juga melakukan pembelajaran dengan metode praktikum. Berdasarkan pada pernyataan Wilson yang beranggapan bahwa pendekatan deduktif merupakan pengembangan sebuah asumsi berdasarkan teori yang telah ada dan membentuk suatu rencana penelitian untuk menguji asumsi tersebut dan Neuman mengatakan bahwa pada pendekatan induktif, tidak ada teori yang digunakan pada awal penelitian, dimulai dengan pengamatan-pengamatan spesifik dan kesimpulannya digeneralisasikan (Zalaghi \& Khazaei, 2016: 24-27), maka dapat dikatakan bahwa sekalipun data pada praktikum di SMA kesimpulannya ditarik dari pengamatan-pengamatan yang spesifik (induksi), tapi karena dikembangkan berdasarkan pada suatu teori/asumsi awal maka pendekatannya adalah deduksi dan kesimpulannya adalah konfirmasi dari asumsi awal (bukan keputusan yang bersifat kemungkinan).

Selain proses pembelajaran, faktor lain yang mempengaruhi keterampilan menarik kesimpulan peserta didik adalah bias kognitif yang dimilikinya. Bias kognitif yang dimiliki oleh seorang peserta didik berbeda-beda, bias kognitif ini dapat membuat seorang peserta didik cenderung memilih kesimpulan yang sama dengan teman kelas atau teman sekelompoknya (Bandwagon effect), hanya memilih data yang menguatkan kesimpulan yang sebenarnya telah dipercayainya sejak awal dan mengabaikan data yang merujuk kepada suatu kesimpulan yang berlawanan dengan apa yang ia percayai (bias konfirmasi), mengubah data atau kepercayaan yang dia miliki jika dia dihadapkan pada suatu pilihan dimana kesimpulan yang dia capai mengarahkannya kepada suatu tindakan yang seharusnya dia lakukan tapi bertentangan dengan kepercayaannya (disonansi kognitif).

\section{.D. SIMPULAN}

Berdasarkan hasil penelitian dan pembahasan yang telah dikemukakan dapat disimpulkan bahwa

1. Keterampilan menarik kesimpulan dalam pembelajaran fisika secara deduksi peserta didik XII MIA SMA Negeri 9 Makassar tahun ajaran 2019/2020 berada pada kategori sedang.

2. Keterampilan menarik kesimpulan dalam pembelajaran fisika secara induksi peserta didik XII MIA SMA Negeri 9 Makassar tahun ajaran 2019/2020 berada pada kategori kurang. 


\section{DAFTAR RUJUKAN}

Bhat, M. A. (2016). The Predictive Power of Reasoning Ability on Academic Achievement. International Journal of Learning, Teaching and Educational Research.

Blumenthal-Barby, J. S., \& Krieger, H. (2015). Cognitive Biases and Heuristics in Medical Decision Making: A Critical Review Using a Systematic Search Strategy. Medical Decision Making, $35(4), 539-557$.

Boeree, C. G. (2016). General Psycology: Psikologi keprbadian,persepsi, kognisi, Emosi, dan Perilaku. Prisma Sophie.

Chang, T. Y., Solomon, D. H., \& Westerfield, M. M. (2016). Looking for Someone to Blame: Delegation, Cognitive Dissonance, and the Disposition Effect: Looking for Someone to Blame. The Journal of Finance, 71(1), 267-302.

Dobelli, R. (2013). The art of thinking clearly (First edition). Harper.

Dozois, D. J., \& Rnic, K. (2015). Core beliefs and self-schematic structure in depression. Current Opinion in Psychology, 4, 98-103.

Evans, J. St. B. T., \& Over, D. E. (2013). Reasoning to and from belief: Deduction and induction are still distinct. Thinking \& Reasoning, 19(3-4), 267-283.

Geisler, N. (1995). Come, Let Us Reason; An introduction To Logical Thinking. B Bakery Academi.

Haryadi, R., \& Pujiastuti, H. (2015). Pengaruh Kemampuan Matematis Terhadap Hasil Belajar Fisika. 4.

Kemendikbud. (2016). Permendikbud No. 22 Tentang Standar Proses Pendidikan Dasar dan Menengah.

Levine, L. E., \& Munsch, J. (2011). Child Development: An active learning approach. SAGE Publication.

Markawi, N. (2015). Pengaruh Keterampilan Proses Sains, Penalaran, dan Pemecahan Masalah terhadap Hasil Belajar Fisika. Formatif: Jurnal Ilmiah Pendidikan MIPA, 3(1).

Moore, B. N., \& Parker, R. (2012). Critical thinking (tenth). Mc Graw Hill.

Nurlailiyah, A., \& Deta, U. A. (2015). Studi Korelasi Antara Kemampuan Matematika Dengan Hasil Belajar Fisika Di Sma Pgri Sumberrejo Bojonegoro Tahun Ajaran 2014/2015. Jurnal Penelitian Fisika dan Aplikasinya (JPFA), 5(2), 64. 
Osborne, J. (2010). Arguing to Learn in Science: The Role of Collaborative, Critical Discourse. Science, 328(5977), 463-466.

Permendikbud. (2016). Permendikbud No. 23 Tentang Standar Penilaian Pendidikan. Kemendikbud.

Prince, M. J., \& Felder, R. M. (2006). Inductive Teaching and Learning Methods: Definitions, Comparisons, and Research Bases. Journal of Engineering Education, 95(2), 123-138.

Reisenzein, R., Horstmann, G., \& Schützwohl, A. (2019). The Cognitive-Evolutionary Model of Surprise: A Review of the Evidence. Topics in Cognitive Science, 11(1), 50-74.

Santrock, J. W. (2011). Educational Psychology (Fifth Edition). Mc Graw Hill.

Sriyansyah, S. P., \& Saepuzaman, D. (2017). Prospective Physics Teachers' Consistency and Scientific Reasoning in the Learning of Force Concept. Proceedings of the 2016 International Conference on Mathematics and Science Education. International Conference on Mathematics and Science Education, Bandung, Indonesia.

Suharto. (2015). Materi Pelatihan Implementasi Kurikulum 2013.

Suriasumantri, J. S. (2015). Ilmu dalam Perspektif. Yayasan Pustaka Obor Indonesia.

Wade, C., Carol, T., \& Maryane, G. (2014). Psikologi. Erlangga.

Wu, T.-Y., \& Lin, C. A. (2017). Predicting the effects of eWOM and online brand messaging: Source trust, bandwagon effect and innovation adoption factors. Telematics and Informatics, 34(2), $470-480$.

Zalaghi, H., \& Khazaei, M. (2016). The Role of Deductive and Inductive Reasoning in Accounting Research and Standard Setting. Asian Journal of Finance \& Accounting, 8(1), 23. 